\title{
Article \\ Strata Movement of the Thick Loose Layer under Strip-Filling Mining Method: A Case Study
}

\author{
Qingliang Chang, Xingjie Yao, Qiang Leng * ${ }^{\mathbb{D}}$, Hao Cheng, Fengfeng $\mathrm{Wu}^{*}$, Huaqiang Zhou * and Yuantian Sun
}

Key Laboratory of Deep Coal Resource Mining of the Ministry of Education, School of Mines, China University of Mining and Technology, Xuzhou 221116, China; zkdcql@cumt.edu.cn (Q.C.); TS21020065A31TM@cumt.edu.cn (X.Y.); TS21020091P21@cumt.edu.cn (H.C.); yuantiansun@cumt.edu.cn (Y.S.)

* Correspondence: lengqiang@cumt.edu.cn (Q.L.); wufengfeng@cumt.edu.cn (F.W.); 2242@cumt.edu.cn (H.Z.)

Citation: Chang, Q.; Yao, X.; Leng, Q.; Cheng, H.; Wu, F.; Zhou, H.; Sun, Y. Strata Movement of the Thick Loose Layer under Strip-Filling Mining Method: A Case Study. Appl. Sci. 2021, 11, 11717. https://doi.org/ 10.3390/app112411717

Academic Editor: Mikhail O. Eremin

Received: 26 October 2021

Accepted: 7 December 2021

Published: 9 December 2021

Publisher's Note: MDPI stays neutral with regard to jurisdictional claims in published maps and institutional affiliations.

Copyright: (c) 2021 by the authors. Licensee MDPI, Basel, Switzerland. This article is an open access article distributed under the terms and conditions of the Creative Commons Attribution (CC BY) license (https:// creativecommons.org/licenses/by/ $4.0 /)$.

\begin{abstract}
Filling mining plays an important role in controlling surface subsidence. To study the movement of overburdened rock in filling mining under thick loose layers, a numerical simulation combing field measurement in CT30101 working face in the Mahuangliang coal mine was tested. The results show that different filling rates and filling body strength have different influences on roof and surface movement. The filling rate has a greater impact, which is the main control factor. The filling stress and roof tensile stress decrease gradually with roadway filling. The filling body stress and roof tensile stress in the first and second rounds are far greater than in the fourth round. After the completion of filling, the first and second round of filling bodies mainly bear the overburden, and the total deformation of the surrounding rock of the main transport roadway is very small, and therefore the displacement of the overburdened rock is controllable. The field monitoring results also show that the overburdened rock became stable after several fillings rounds. Combing the numerical modeling and field tests results, this study can be a guideline for similar geological conditions especially for coal mining under thick loose layers and thin bedrock.
\end{abstract}

Keywords: extremely thick loose layer; roadway by lane filling mining; overburden movement; numerical simulation

\section{Introduction}

The strength of the loose layer is far less than that of the ordinary rock layer. The loose layer not only undergoes consolidation and compression deformation but also loads the bedrock surface, aggravating the destruction of rock formations and mining subsidence, resulting in damage to surface buildings (structures) [1-4]. Therefore, the law of overburden and surface movement and deformation in loose layer mining is quite different from conventional mining.

Some scholars have used fractal-related theories to study the mining with thick loose layers and thin bedrock, and they found that the evolution characteristics of overlying rock fractures have good self-similarity and fractal characteristics. Some have studied the mechanical properties of the thick loose layer, and they pointed out that the maximum surface subsidence value increases with the thickness of the loose layer, and decreases with the increase in the friction angle and cohesion of the loose layer [5-9]. Furthermore, the relevant research across the world is shown as follows. According to the engineering geological conditions of the Shandong mining area, the law of surface movement and deformation in thick loose layers and large mining height mining is studied $[10,11]$. Based on the measured data of the Lianghuai mining area, the influence of geological mining conditions on boundary angle and movement angle is analyzed in detail. It is concluded that there is a logarithmic relationship between comprehensive movement angle, comprehensive boundary angle, and the thickness of the Tertiary and Quaternary loose layer [12,13]. The change characteristics of topographic factors such as slope direction, coefficient of variation, and slope before and after mining subsidence show that all topographic factors are changed 
by mining subsidence $[14,15]$. Under the mining condition of thin bedrock and thick loess layer, the subsidence deformation of loess layer and bedrock subsidence keep moving synchronously. The model of deep wide strip mining under super thick loose layer is established to study the relationship between the change in loose layer thickness, surface movement law, and subsidence coefficient [16]. The calculation of surface rock movement parameters of coal mine under loess gully terrain is based on slope stability analysis and computer inversion simulation. To evaluate surface asymmetric settlement in a mining area with thick bedrock and a thin loose layer, a superposition model is proposed. Time evolution of mining-related residual subsidence monitored over 24 years using InSAR in southern Alsace, France, is also investigated [17].

Others used numerical simulation to study the influence of loose layer thickness/base rock thickness, buried depth/coal thickness, and three mechanical parameters of tensile strength, cohesion, and internal friction on ground subsidence [18-22]. Some have analyzed the stability of the key water-proof layer of the filling working face through theoretical analysis, numerical simulation, and actual measurement, and they revealed the crack height and change law of the overburdened rock under the thin base rock and thick loose layer [23-27]. Some researchers have established a mechanical model of the thin bedrock face structure, and they pointed out that a thick clay layer with greater bearing capacity can be combined with a thin bedrock to form a stable structure [28-31]. Some scholars regarded the thick loose layer and single thin bedrock as the load-bearing structure acting on the solid filling material, and they established a single-layer thin bedrock elastic continuous beam model [32-35]. The above-mentioned research has enriched the theory and practice of overlying rock movement and deformation in mining under thick loose layers [36-38].

However, the theory of paste filling mining has not been adopted for the shallow buried extremely thick loose layer and thin bedrock, and there are few cases of paste filling mining under such conditions. Therefore, taking the Mahuangliang coal mine as the geological background, this paper studies the law of overburden migration in the roadway by paste filling to guide the production of such conditions. First, a short description of the project is discussed. Second, a 3D model about the project is established and analyzed. Last, the field test and monitoring are conducted and discussed.

\section{Project Overview}

Mahuangliang is located on the border between Mu Us Desert and Loess Plateau in Northern Shaanxi. The surface is completely covered by Quaternary loose sediments. The average thickness of Neogene and Quaternary unconsolidated layer overlying the coal seam is $168.7 \mathrm{~m}$, and the average thickness of bedrock is $25 \mathrm{~m}$. It belongs to the occurrence characteristics of typical extremely thick unconsolidated layer and thin bedrock. Due to the medium characteristics of the loose layer, its strength is far lower than that of the general rock layer and will not produce a layered effect. It will aggravate the rock layer damage and mining subsidence, resulting in the damage of surface buildings (structures). Therefore, this paper takes the first mining experimental working face CT30101 of compressed coalfilling mining of buildings (structures) in the Mahuangliang mine as the research object, as shown in Figure 1.

The average buried depth of CT30101 working face is $193.7 \mathrm{~m}$, and the average thickness of the coal seam is $10.4 \mathrm{~m}$. The 30,401 working face is arranged on both sides, and two working faces are arranged in parallel with three roadways. The strip-mining width is $8 \mathrm{~m}$, as shown in Figure 2. The direct roof is mainly composed of mudstone and silty mudstone with a thickness of $1.5 \sim 3.7 \mathrm{~m}$. The basic roof is mainly medium coarse-grained sandstone with an average thickness of $22.4 \mathrm{~m}$. The monitoring stations are set in the main transportation roadway shown in Figure 2 to monitor the displacement of the roadway. Before and after the mining and filling, the displacement is recorded not only around the roadway surface but also in the rock mass ( $8.5 \mathrm{~m}$ away from the surface) from January 2019 to June 2020. 


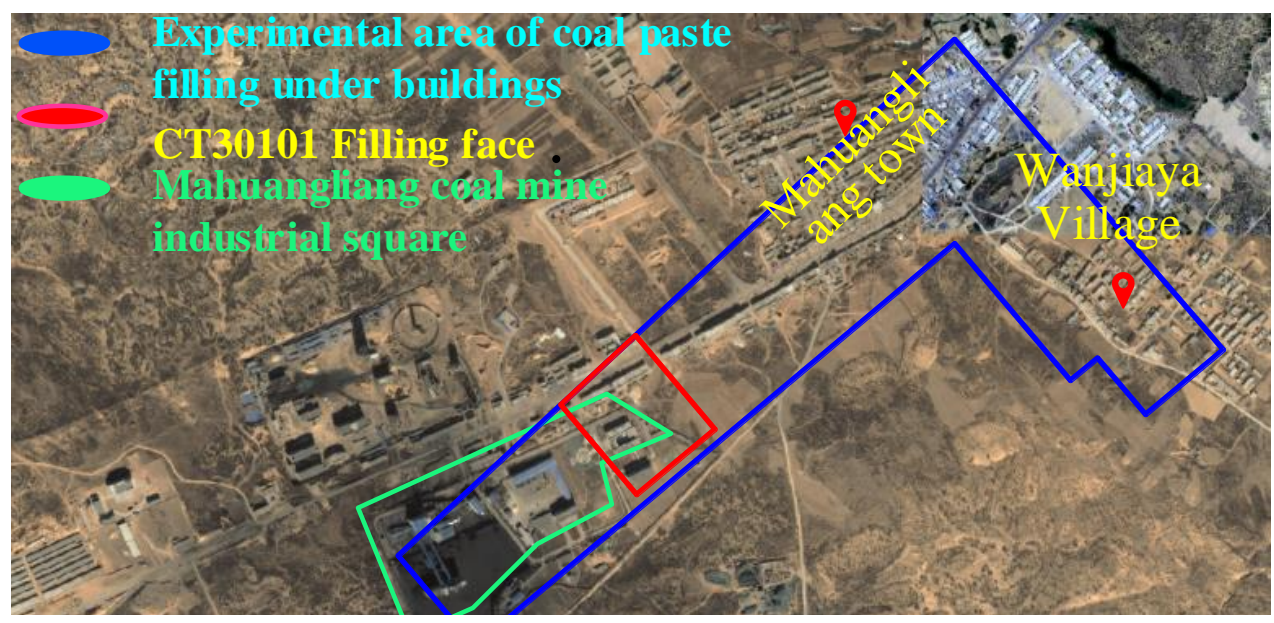

Figure 1. Map of CT30101 working face.

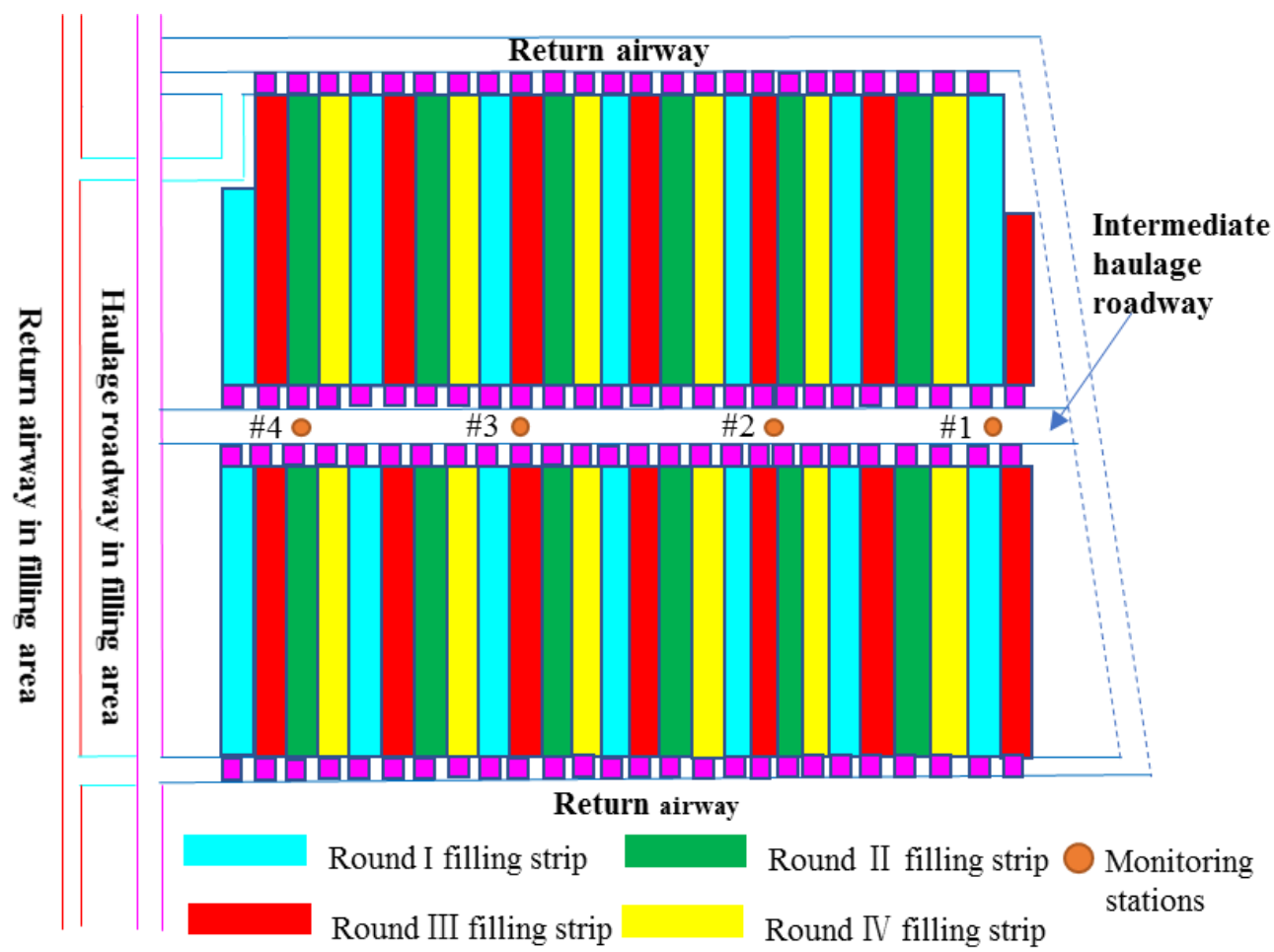

Figure 2. Schematic diagram of strip mining with paste filling in CT30101 working face.

\section{Numerical Simulation Analysis of Overburden Movement and Failure}

3.1. Model Establishment

The FLAC3D (V5.0) is applied to establish the numerical model. Combined with the geological conditions of CT30101 working face in the Mahuangliang coal mine, we establish a $520 \mathrm{~m} \times 150 \mathrm{~m} \times 234 \mathrm{~m}$ numerical calculation model. Considering the influence of the mining movement, $100 \mathrm{~m}$ coal pillars are reserved on both sides of the model. The upper part of the coal seam is built to the surface to observe the surface movement and deformation as shown in Figure 3. The upper boundary of the model is the free boundary. The lower boundary is a fully constrained boundary with fixed horizontal and vertical displacement. The other boundaries are single constraint boundaries with fixed horizontal displacement. The Mohr-Coulomb elastic-plastic constitutive model is selected. The simulated mechanical parameters of surrounding rock consider external force 
factors such as weathering and structure, and the weakening is classified according to the engineering rock mass, as shown in Table 1.

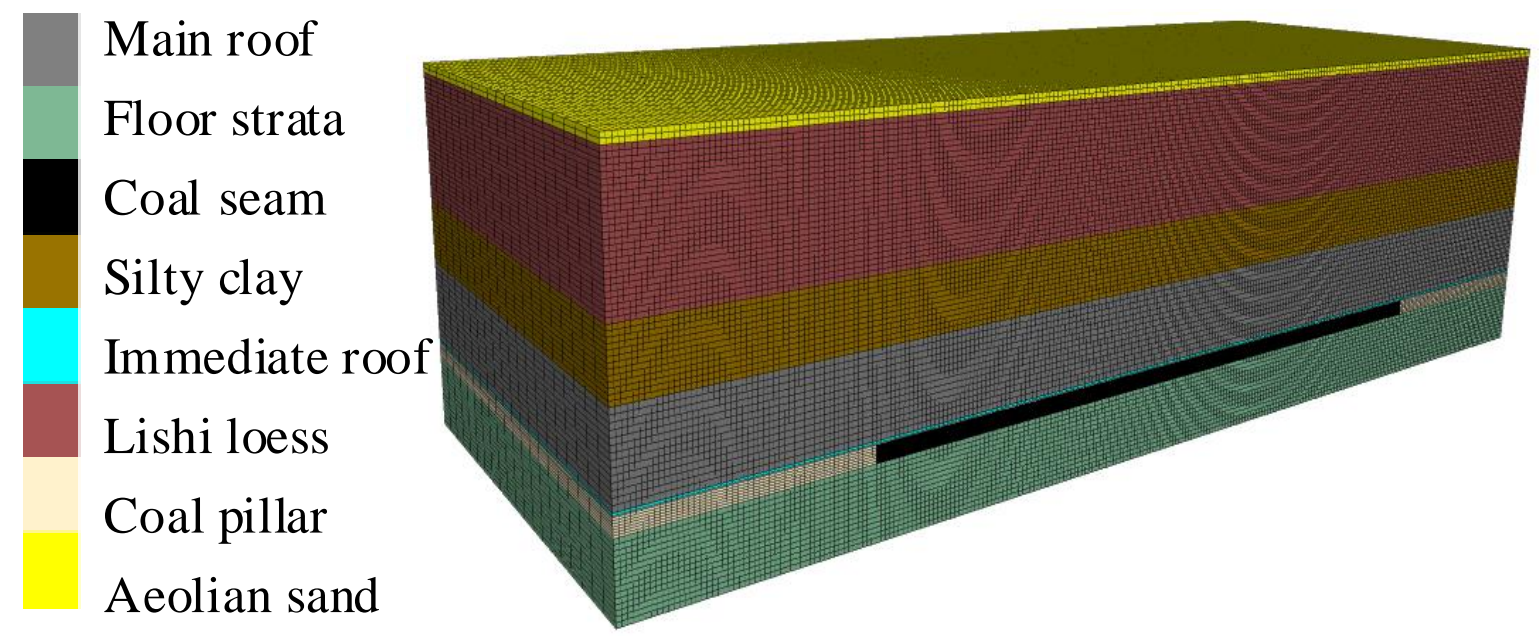

Figure 3. Numerical calculation model diagram.

Table 1. Mechanical parameters of surrounding rocks.

\begin{tabular}{|c|c|c|c|c|c|c|c|}
\hline Rock Formation & $\begin{array}{l}\text { Thickness } \\
\text { /m }\end{array}$ & $\begin{array}{l}\text { Density } \\
/ \mathrm{kg} / \mathrm{m}^{3}\end{array}$ & $\begin{array}{l}\text { Bulk } \\
\text { Modulus } \\
\text { /MPa }\end{array}$ & $\begin{array}{l}\text { Shear } \\
\text { Modulus } \\
/ \mathrm{MPa}\end{array}$ & $\begin{array}{c}\text { Tensile } \\
\text { Strength } \\
/ \mathrm{MPa}\end{array}$ & $\begin{array}{c}\text { Internal Friction } \\
\text { Angle } \\
\digamma^{\circ}\end{array}$ & $\begin{array}{c}\text { Cohesion } \\
\text { /MPa }\end{array}$ \\
\hline Aeolian sand & 5.5 & 1650 & 133 & 79 & 0.00 & 8 & 0.00 \\
\hline Lishi loess & 88.2 & 1950 & 233 & 185 & 0.20 & 10 & 0.01 \\
\hline Silty clay & 75 & 2240 & 609 & 469 & 1.20 & 25 & 0.02 \\
\hline Medium coarse sandstone & 22.4 & 2250 & 1436 & 1062 & 2.50 & 40 & 2.81 \\
\hline Sandy mudstone & 2.6 & 2430 & 1047 & 1028 & 0.85 & 41 & 1.93 \\
\hline Coal seam & 10.4 & 1420 & 340 & 300 & 0.50 & 36 & 3.40 \\
\hline Argillaceous siltstone & 30 & 2760 & 780 & 402 & 3.90 & 39 & 3.14 \\
\hline Filling body & - & 1990 & 389 & 233 & 1.00 & 24 & 0.79 \\
\hline
\end{tabular}

\subsection{Simulation Scheme}

(1) Scheme 1: When the strip width is $8 \mathrm{~m}$ and the strength of the fixed filling body is $5 \mathrm{MPa}$, the movement and deformation of roof surrounding rock and surface after four-wheel strip filling with different filling rates are studied.

(2) Scheme 2: When the strip width is $8 \mathrm{~m}$ and the fixed filling rate is $98 \%$, study the movement and deformation of roof surrounding rock and surface after four-wheel strip filling.

\subsection{Influence of Filling Ratio on Movement and Failure of Overburden}

(1) Analysis of overburden and surface deformation

After four rounds of strip filling mining with different filling rates, the movement and deformation of overburden and surface are shown in Figure 4.

As can be seen from Figure 4, in strip paste filling mining, the filling rate decreases and the surface subsidence value increases significantly. The surface subsidence value is the largest in the mining center of the working face, and the subsidence value is symmetrical. When the filling rate is $98 \%, 97 \%$, and $95 \%$, the maximum surface subsidence values are $180 \mathrm{~mm}, 287 \mathrm{~mm}$, and $377 \mathrm{~mm}$, respectively. When the filling rate is $98 \%, 97 \%$, and $95 \%$, the surface horizontal displacement ranges are $92 \mathrm{~mm} \sim-86 \mathrm{~mm}, 148 \mathrm{~mm} \sim-135, \mathrm{~mm}$ and $200 \mathrm{~mm} \sim-173 \mathrm{~mm}$, respectively. The increase of surface subsidence and horizontal displacement makes the horizontal deformation and increases the inclined deformation 
and curvature. The law of roof subsidence is consistent with that of surface subsidence. When the filling rate is $98 \%, 97 \%$, and $95 \%$, the maximum subsidence values of the roof are $203 \mathrm{~mm}, 319 \mathrm{~mm}$, and $395 \mathrm{~mm}$, respectively. Among them, the stripped roof subsidence values of different rounds of mining and filling are also different. The strip roof subsidence of the fourth round is the largest, followed by the third round and the second round, and the first round is the smallest. This also shows that the roof subsidence value gradually accumulates with strip mining.

(a)

Roof strike position/m

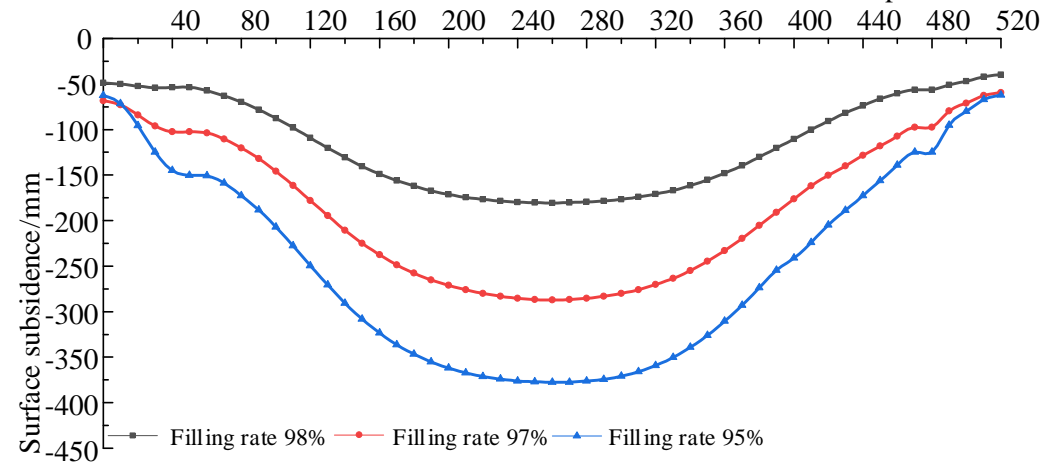

(b)

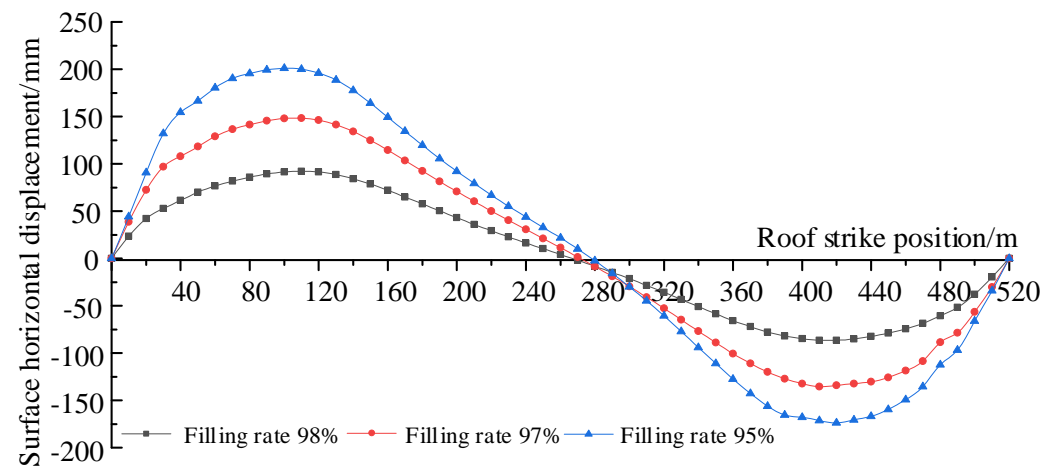

(c)

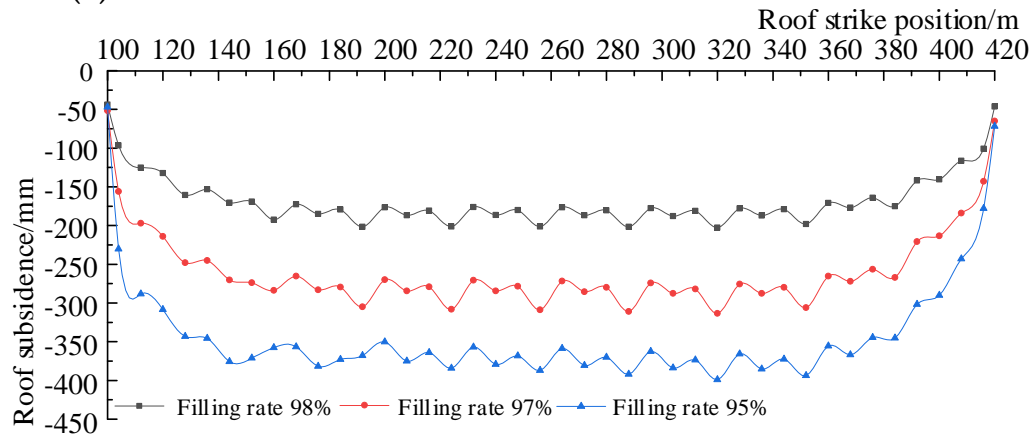

Figure 4. Curves of overburden and surface deformation with different filling rates. (a) The ground sinks, (b) Horizontal displacement of the ground surface, (c) The roof sinks.

(2) Stress analysis of overburden and backfill

After four rounds of strip filling mining with different filling rates, the vertical stress change curve of the filling body and the tensile stress curve of the roof is shown in Figures 5-7, respectively.

As can be seen from Figure 5, the coal walls on both sides will produce certain stress concentrations after strip paste filling mining, and the magnitude of stress concentration will change with the change in filling rate. When the filling rate is $98 \%, 97 \%$, and $95 \%$, the 
peak values of advance bearing stress are $8.96 \mathrm{MPa}, 9.63 \mathrm{MPa}$, and $9.25 \mathrm{MPa}$, respectively. The stress concentration factors are 2.67, 2.86, and 2.75. As can be seen from Figure 6, after the four strips mining face with paste filling is fully mined, the stress of filling body in different circulating strips is different. In the first round and the fourth round, the force on the filling body decreases in turn and changes with the change in the filling rate. When the filling rate is $98 \%$, the filling stress of the first round to the fourth round is $4.67 \mathrm{MPa}$, 4.33 MPa, 1.66 MPa, and $0.82 \mathrm{MPa}$, respectively. When the filling rate is $97 \%$, the filling stress of the first round to the fourth round is $5.10 \mathrm{MPa}, 4.95 \mathrm{MPa}, 1.73 \mathrm{MPa}$, and $0.24 \mathrm{MPa}$, respectively. When the filling rate is $95 \%$, The filling stress of the first round to the fourth round is $4.42 \mathrm{MPa}$, $4.79 \mathrm{MPa}, 1.67 \mathrm{MPa}$, and $0.45 \mathrm{MPa}$, respectively. The first and second strip fillings mainly support the overburdened strata. As can be seen from Figure 7, the tensile stress of strip roof in filling mining is also different in different stages, and changes with the change in the filling rate. When the filling rate is $98 \%, 97 \%$, and $95 \%$, the maximum tensile stress of strip roof in the first round of mining is $1.95 \mathrm{MPa}, 2.69 \mathrm{MPa}$, and $2.49 \mathrm{MPa}$ respectively. The maximum tensile stress of strip roofs in the second round of mining is $1.63 \mathrm{MPa}, 2.26 \mathrm{MPa}$, and $2.87 \mathrm{MPa}$, respectively. The maximum tensile stress of strip roofs in the third round of mining is $0.57 \mathrm{MPa}, 0.84 \mathrm{MPa}$, and $0.94 \mathrm{MPa}$, respectively. The maximum tensile stress of strip roofs in the fourth round of mining is $0.23 \mathrm{MPa}, 0.37 \mathrm{MPa}$, and $0.50 \mathrm{MPa}$, respectively.
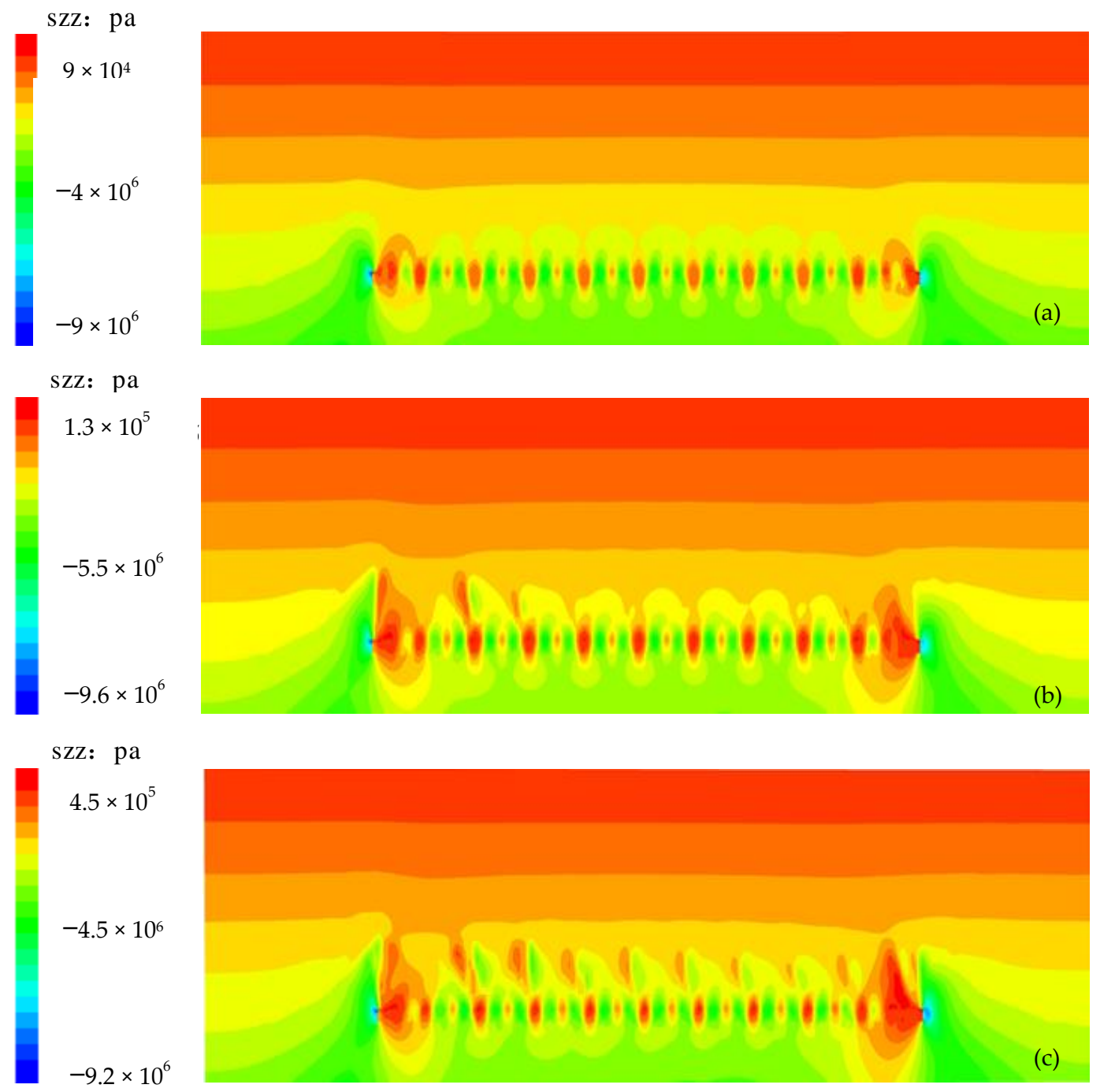

Figure 5. Vertical stress at the end of four strips filling with different filling rates. (a) Filling rate is $98 \%$, (b) Filling rate is $97 \%$, (c) Filling rate is $95 \%$. 


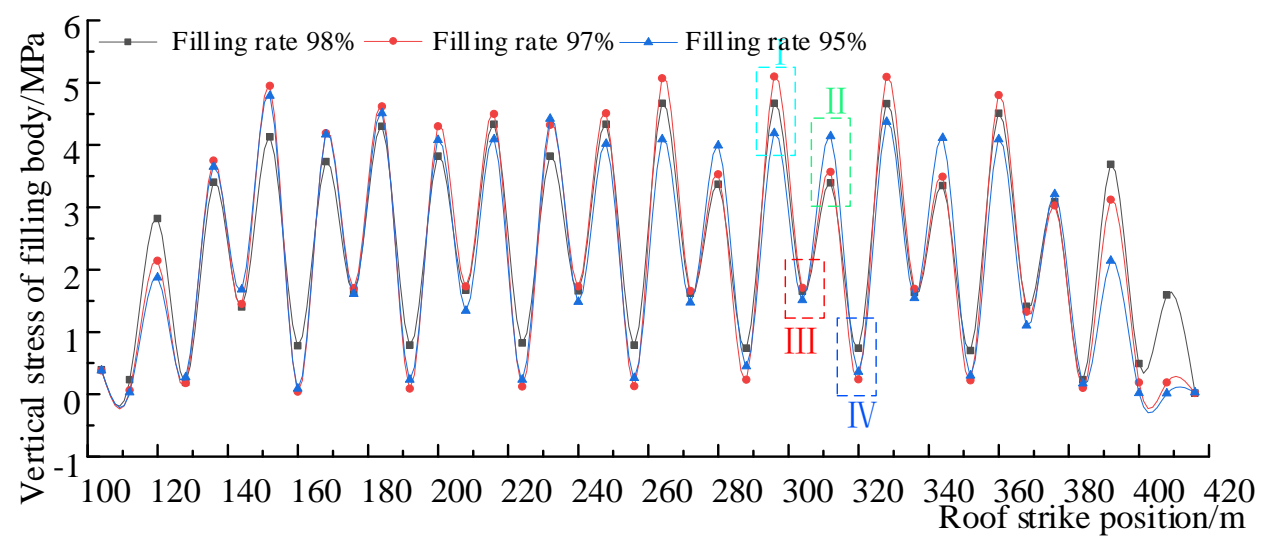

Figure 6. Vertical stress curve of filling the body with different filling rates. I means first peak/valley value in a circle tensile stress, II means second peak/valley value in a circle tensile stress, III means third peak/valley value in a circle tensile stress, IV means forth peak/valley value in a circle tensile stress.

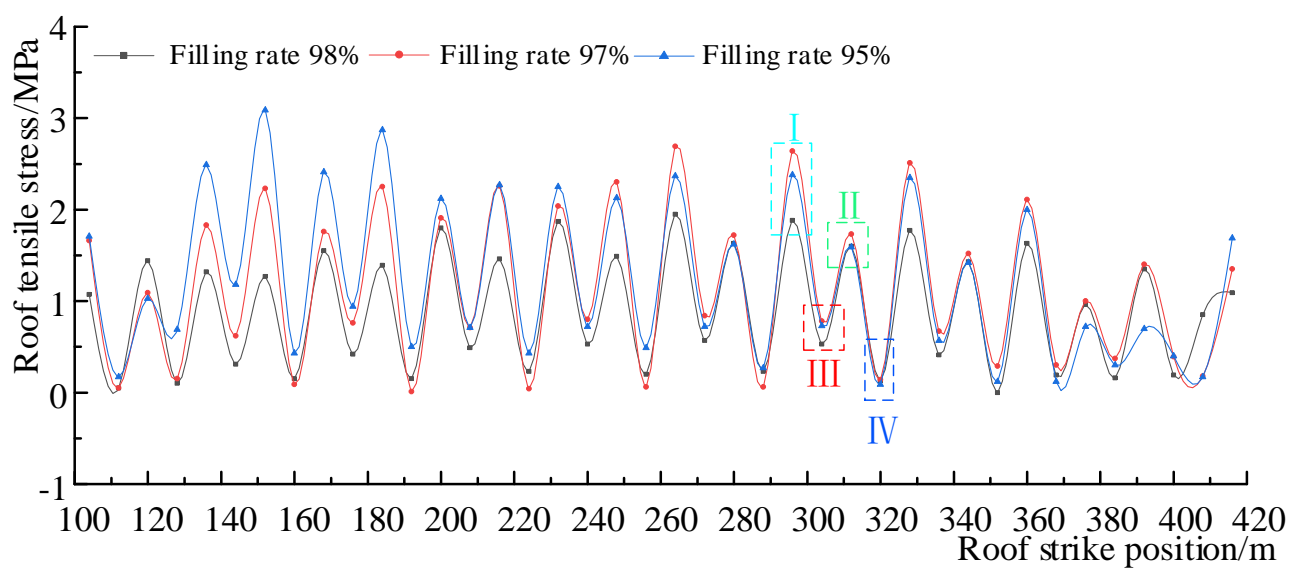

Figure 7. Change curve of tensile stress of roof with different filling rates. I means first peak/valley value in a circle tensile stress, II means second peak/valley value in a circle tensile stress, III means third peak/valley value in a circle tensile stress, IV means forth peak/valley value in a circle tensile stress.

In conclusion, the strength of the filling body is certain, and different filling rates have a great impact on the movement and deformation of the overburden, surface, and filling body. To ensure the filling effect, it is necessary to reduce the distance between the under-connected top and the top and bottom plate before filling, to improve the filling rate.

\subsection{Influence of Backfill Strength on Overburden Movement and Failure}

(1) Analysis of overburden and surface deformation

After four rounds of strip filling mining with different filling strengths, the movement and deformation of overburden and surface are shown in Figure 8.

As can be seen from Figure 8, in strip paste filling mining, different filling strength has little effect on surface subsidence, horizontal movement, and roof subsidence. The movement deformation law is consistent with the influence law of filling rate. When the filling rate is $98 \%$, the maximum surface subsidence is $183 \mathrm{~mm}$. The range of surface horizontal displacement is $92 \mathrm{~mm} \sim-86 \mathrm{~mm}$. The maximum subsidence of the roof occurs during the first round of strip filling, and its value is $202 \mathrm{~mm}$. 

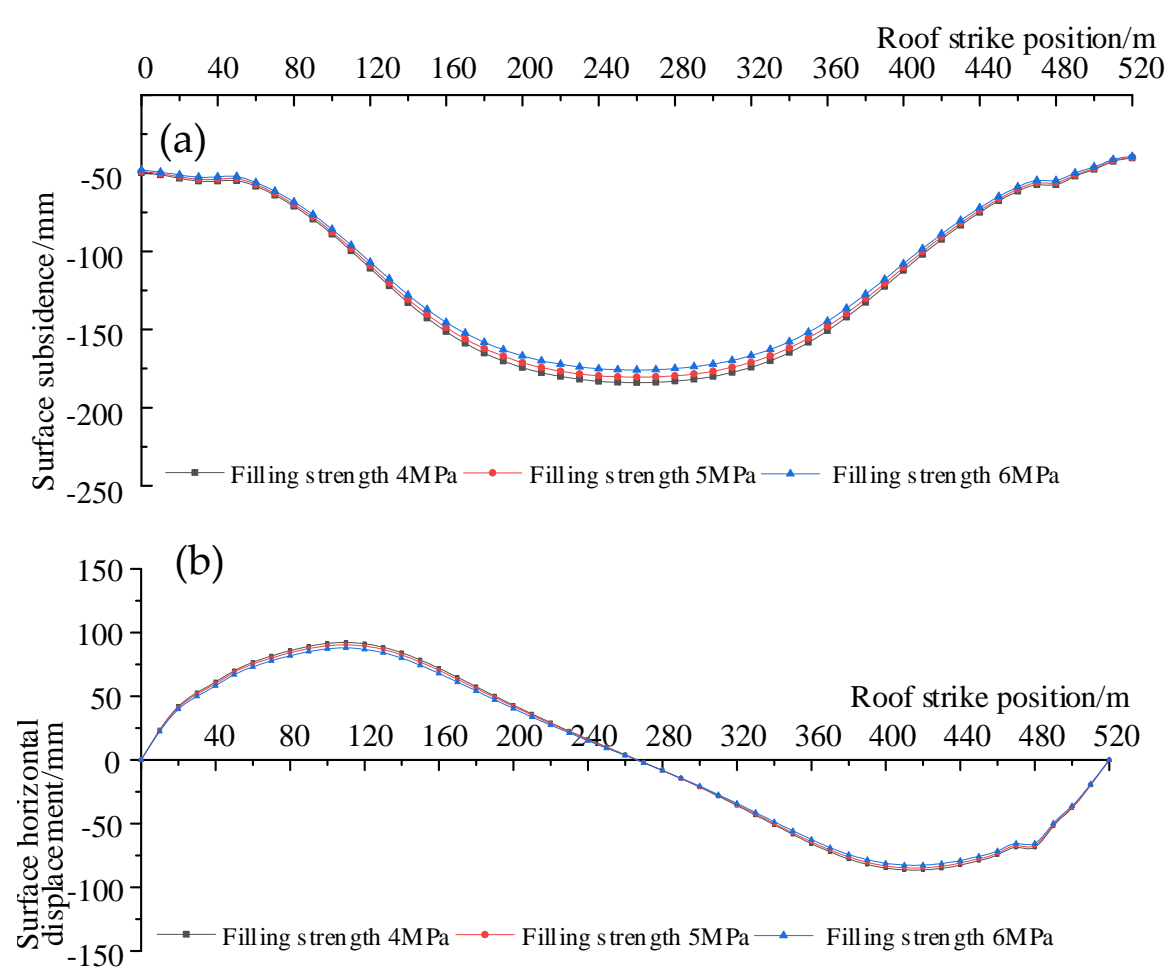

Roof strike position/m

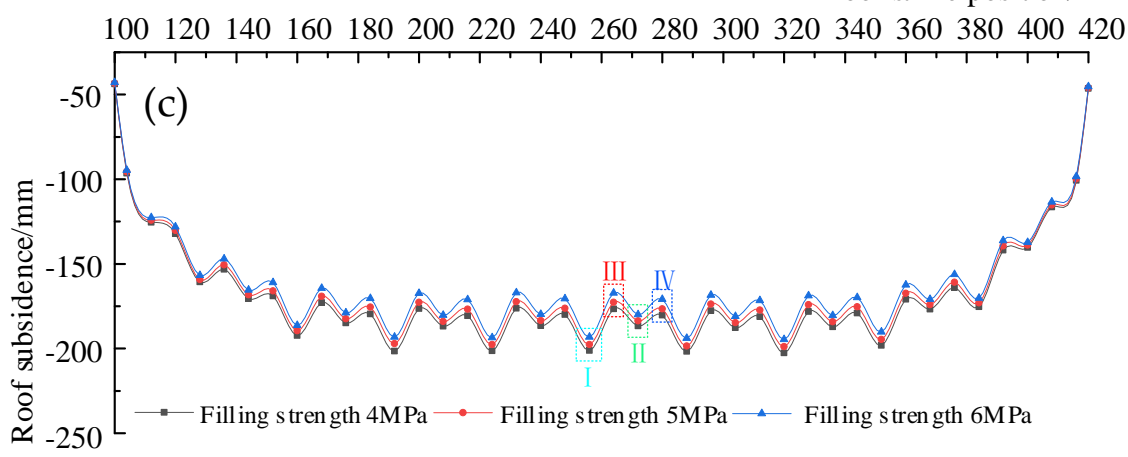

Figure 8. Curves of overburden and surface deformation with different filling strengths. (a) The ground sinks, (b) Horizontal displacement of the ground surface, (c) The roof sinks. I means first peak/valley value in a circle tensile stress, II means second peak/valley value in a circle tensile stress, III means third peak/valley value in a circle tensile stress, IV means forth peak/valley value in a circle tensile stress.

\section{(2) Stress analysis of overburden and backfill}

After four rounds of strip filling mining with different filling strengths, the vertical stress change curve of the filling body and the tensile stress curve of the roof are shown in Figures 9 and 10, respectively.

As can be seen from Figures 9 and 10, when the filling rate is 98\%, different filling strength is selected for strip filling mining, and the compressive stress of the overlying rock is the same. However, the maximum compressive stress of the first to fourth round strip fillings gradually decreases, which are $4.76 \mathrm{MPa}, 4.43 \mathrm{MPa}, 1.67 \mathrm{MPa}$, and $0.82 \mathrm{MPa}$, respectively. It shows that in the process of strip filling, the first and second strip filling bodies are mainly responsible for the mining stress of the overlying strata, followed by the third strip filling body, and the fourth strip filling body. Compared with the influence of filling rate on the tensile stress of the roof, different filling strength has less influence on the tensile stress of the roof. It still shows that the maximum tensile stress of the filling roof 
in the first round is $2.1 \mathrm{MPa}$, followed by the second and third round, and the tensile stress of the roof in the fourth round is reduced to $0.1 \mathrm{MPa}$.

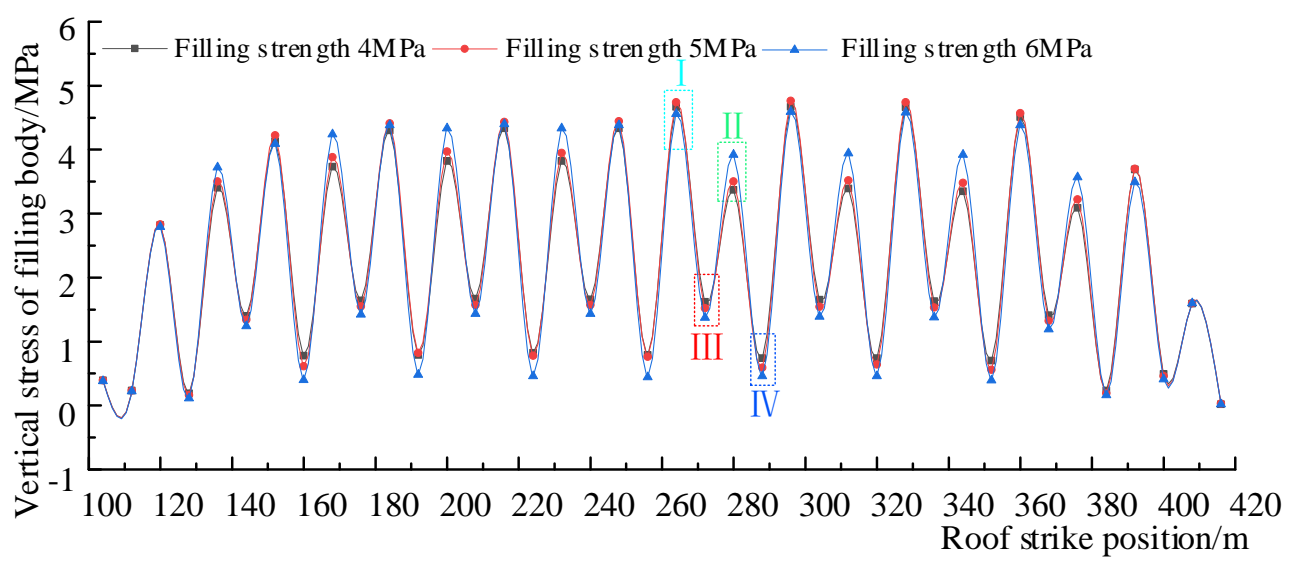

Figure 9. Vertical stress curve of filling the body with different strengths. I means first peak/valley value in a circle tensile stress, II means second peak/valley value in a circle tensile stress, III means third peak/valley value in a circle tensile stress, IV means forth peak/valley value in a circle tensile stress.

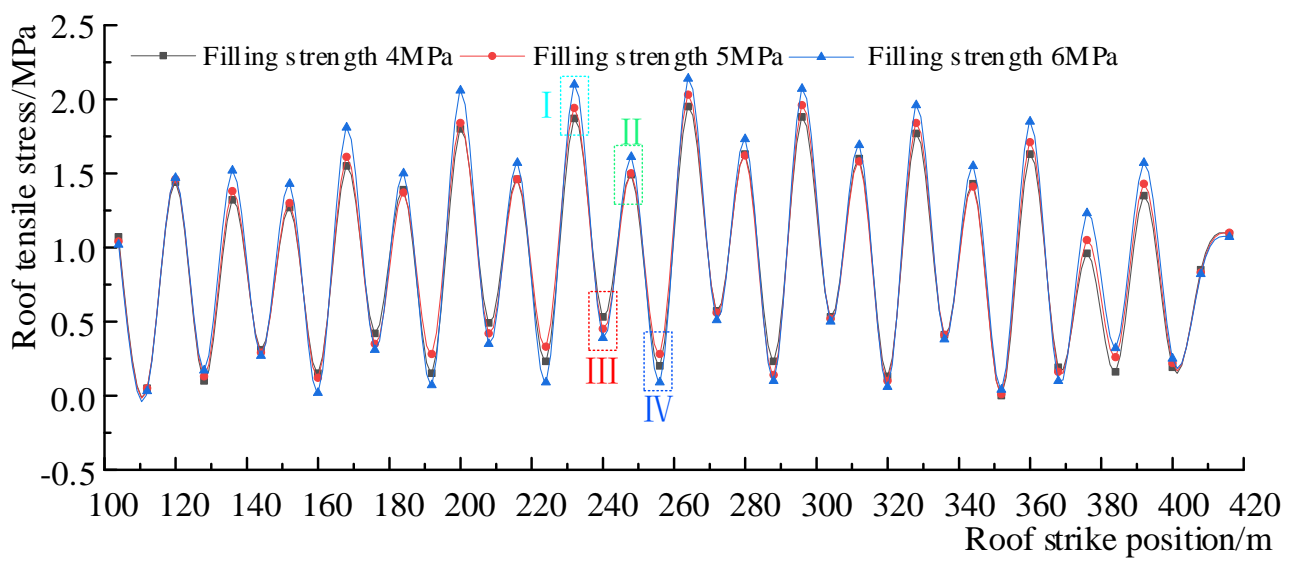

Figure 10. Variation curve of tensile stress of roof with different filling strength. I means first peak/valley value in a circle tensile stress, II means second peak/valley value in a circle tensile stress, III means third peak/valley value in a circle tensile stress, IV means forth peak/valley value in a circle tensile stress.

In conclusion, the filling rate is certain, and the strength of the filling body has little effect on the movement and deformation of the overburden, surface, and filling body, which can meet the requirements.

\section{Engineering Practice of Strip Paste Filling}

\subsection{Roadway Surrounding Rock Deformation Monitoring}

Three surrounding rock deformation measuring stations are set in the middle main transportation roadway of CT30101 working face, which is away from the stopping line. The monitoring results are shown in Figure 11. 
(a)
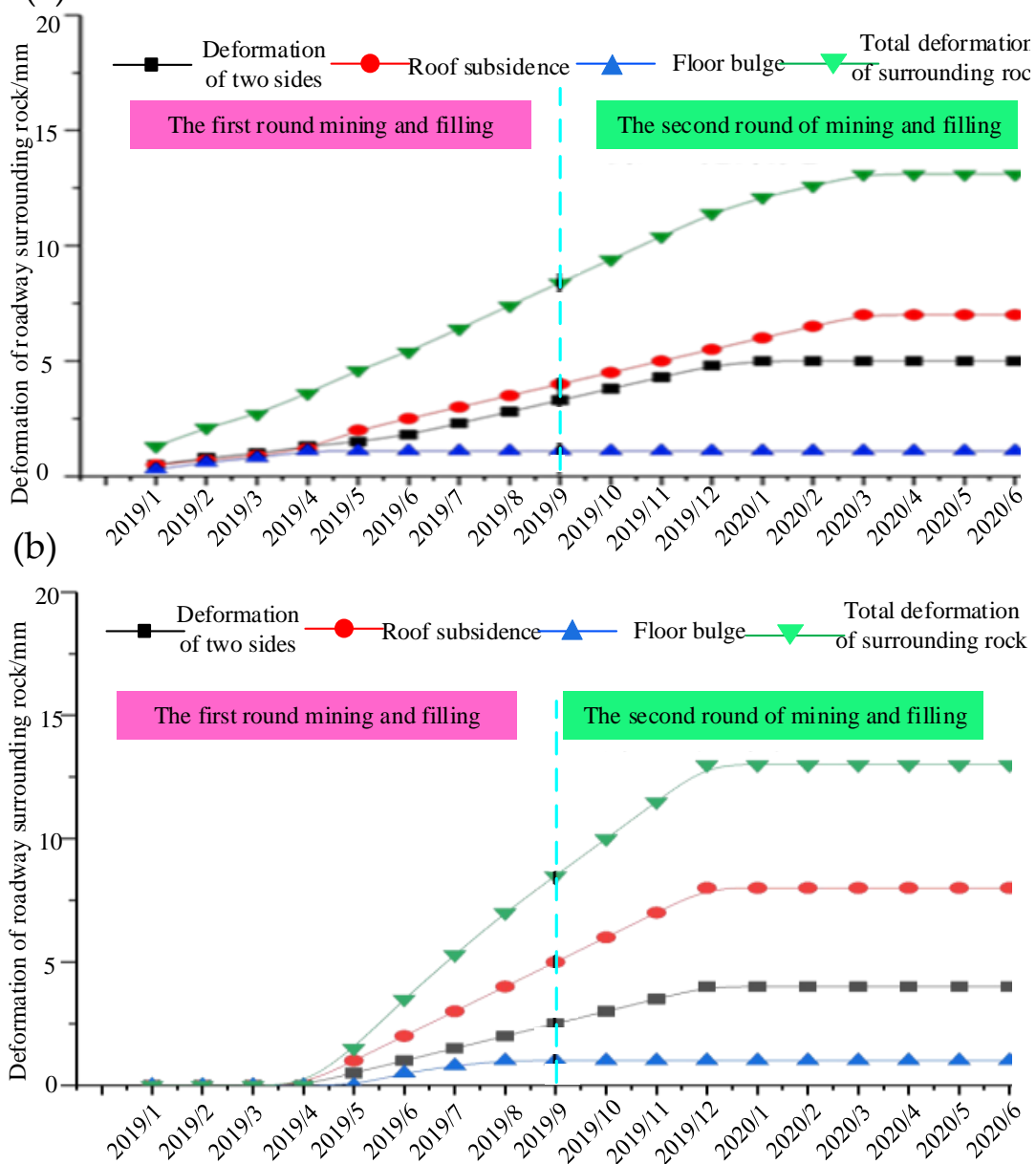

(c)

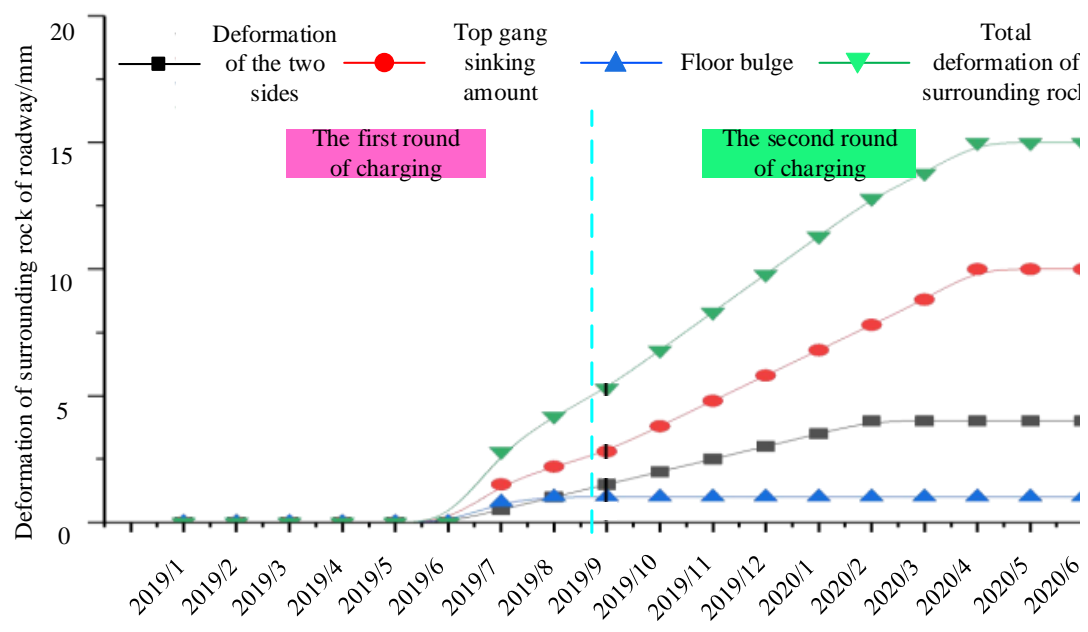

Figure 11. Deformation monitoring curve of surrounding rock of main haulage roadway in CT30101 working face. (a) 1\# Station. (b) 2\# Station. (c) 3\# Station.

As can be seen from Figure 11, at the initial stage of mining, the surrounding rock is not deformed. After the first round of mining and filling, the maximum total deformation of the two sides is $2.5 \mathrm{~mm}$, the maximum subsidence of the top is $5 \mathrm{~mm}$, the maximum bottom heave is $0.5 \mathrm{~mm}$, and the maximum total deformation is $8 \mathrm{~mm}$. After the second round of mining and filling, the maximum total deformation of the two sides is $5 \mathrm{~mm}$, the maximum top subsidence is $10 \mathrm{~mm}$, the maximum bottom heave is $1 \mathrm{~mm}$, and the 
maximum total deformation is $16 \mathrm{~mm}$. Monitoring results show that, after the completion of the second round of filling mining in front of CT30101, the deformation of the main transport roadway of the working face is very small, which will not affect the normal production of the working face.

\subsection{Monitoring of Overburden Displacement}

CT30101 working face is mined in four rounds. Four survey stations are selected in the main transportation roadway of CT30101 working face, which is away from the stopping line. During the first, second, third, and fourth rounds of mining, the approach of the top and bottom plate shall be observed, and the measuring points with a depth of $8.5 \mathrm{~m}$ shall be selected. The displacement of overburden after two rounds of mining in front of СТ30101 is shown in Figure 12.

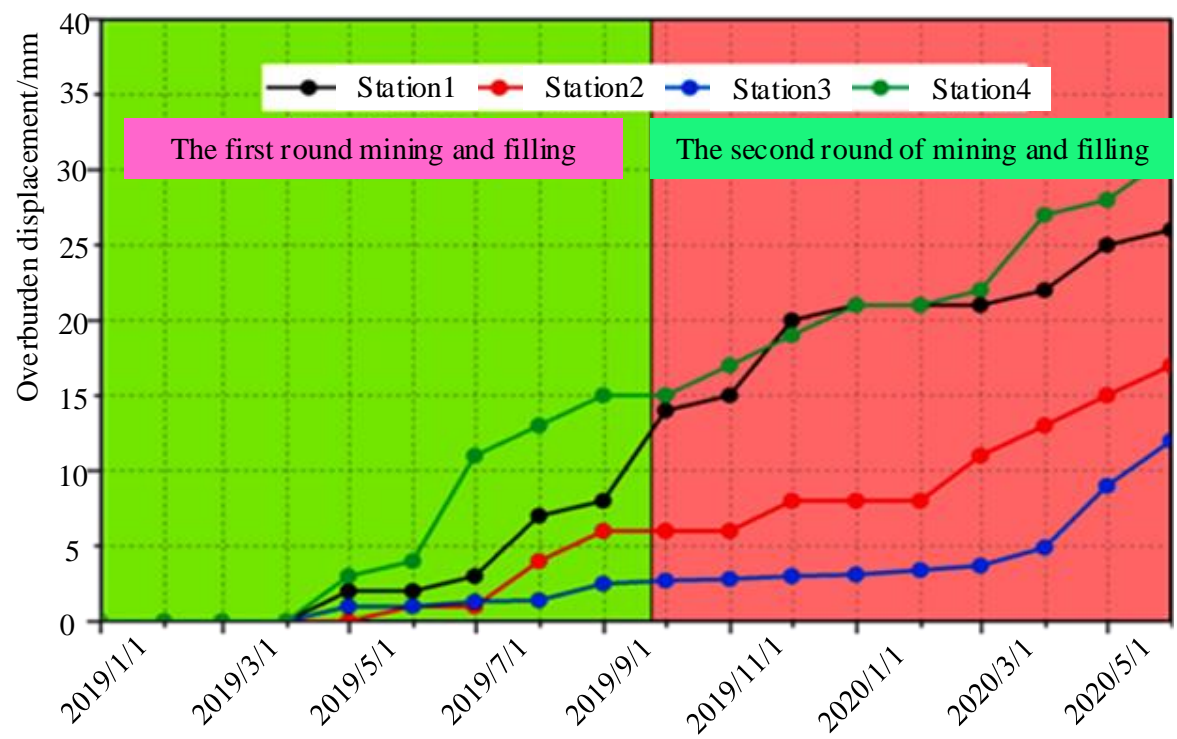

Figure 12. Monitoring curve of overburden movement in CT30101 working face.

As can be seen from Figure 12, the overburden did not move within four months before the first round of mining, and the roof began to move slowly after the fourth month. After the first round of mining and filling, the maximum displacement of overburden was close to $15 \mathrm{~mm}$. After the first round of mining and filling is completed, the second round of mining and filling is carried out. It can be seen that the displacement of overburden changes slowly, but the change is relatively gentle. The maximum overburden displacement is around $30 \mathrm{~mm}$ and according to the requirement in this mine, the results can keep the surface stability, which means that under the joint action of the remaining coal pillar and filling body in CT30101 working face, the overburden deformation is controllable and will not affect the normal production of the working face.

\subsection{Filling Stress Monitoring}

We selected the observation strip in the middle of the advancing direction of the working face, and each observation strip is equipped with 3 borehole stress meters to test the pressure changes in the middle, secondary middle, and near the edge of the filling strip length direction. The borehole stress gauge for observing the strip filling body shall be installed around $7 \mathrm{~d}$ after the filling body solidifies and shall not exceed $10 \mathrm{~d}$ at the latest. Drill holes from the upper end of the filling strip and arrange three holes in a triangle. Among them, the drilling depth for measuring the edge stress of the filling body is about $2 \mathrm{~m}$ deep into the filling body. Measure the stress in the middle area of the filling zone, and the drilling depth is about $15 \mathrm{~m}$. The stress in the sub middle area of the filling zone 
was measured, and the drilling depth was about $7 \mathrm{~m}$. The stress monitoring curve of three measuring points of the strip filling body is shown in Figure 13.

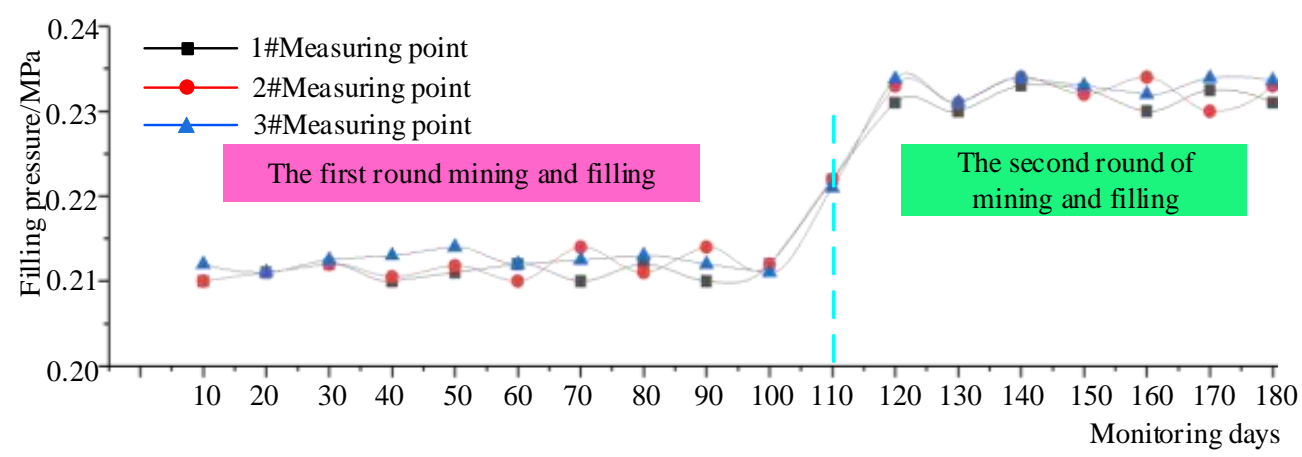

Figure 13. Stress monitoring curve of the filling body.

As can be seen from Figure 13, after the first round of filling and mining, the stress value of the filling body is generally between $0.21 \sim 0.215 \mathrm{MPa}$. However, at the beginning of the second round of filling mining, the stress value of the first round of filling body increases, which is generally between $0.23 \sim 0.235 \mathrm{MPa}$. The results show that the first and second round filling bodies mainly bear their pressure in the first two rounds of mining and filling operation. The overburden pressure has not been transferred to the filling body in the first round of mining and filling operation, and the overburden pressure begins to transfer to the first round of filling body in the second round of mining and filling operation.

\section{Conclusions}

(1) Different filling rates and filling strength have different effects on the roof surrounding rock and surface movement and deformation. To ensure the filling effect, it is mainly to improve the filling rate.

(2) The filling stress and roof tensile stress gradually decrease with the roadway filling, but the first and second rounds of filling stress and roof tensile stress are much greater than the fourth round.

(3) After the first round and the second round of roadway filling, the maximum total deformation of the surrounding rock of the main transportation roadway is $8 \mathrm{~mm}$ and $16 \mathrm{~mm}$, respectively. Therefore, the movement of overburden is controllable, which will not affect the normal production of the working face.

(4) During the first round of mining and filling, the overburden pressure is not transferred to the filling. During the second round of filling, the stress value of the first round of filling increases.

Author Contributions: Conceptualization, Q.C. and Q.L. methodology, X.Y.; investigation, Q.C.; writing—original draft preparation, Q.C., Q.L. and H.C.; writing—review and editing, F.W., H.Z. and Y.S.; supervision, Q.C.; funding acquisition, Q.C. and H.Z. All authors have read and agreed to the published version of the manuscript.

Funding: This research was supported by the projects of "the Fundamental Research Funds for the Central Universities (2020ZDPY0221, 2021QN1003)”, “National Natural Science Foundation of China (52174130, 52104106, 52174089)" Basic Research Program of Xuzhou (KC21017).

Institutional Review Board Statement: Not applicable.

Informed Consent Statement: Not applicable.

Data Availability Statement: The data presented in this study are available on request from the corresponding author. The data are not publicly available due to privacy.

Acknowledgments: The authors are grateful to Gaohe coal mine. 
Conflicts of Interest: The authors declare no conflict of interest.

\section{References}

1. Zhao, Y.X.; Dong, J.F.; Wu, Y.Y.; Jin, W.L. Corrosion-induced concrete cracking model considering corrosion product-filled paste at the concrete/steel interface. Constr. Build. Mater. 2016, 116, 273-280. [CrossRef]

2. Doherty, J.P.; Hasan, A.; Suazo, G.H.; Fourie, A. Investigation of some controllable factors that impact the stress state in cemented paste backfill. Can. Geotech. J. 2015, 52, 1901-1912. [CrossRef]

3. Liu, Y.; Lu, Y.; Wang, C.X.; Cui, B.Q.; Guo, H.; Li, H.; Guo, Y.L. Effect of sulfate mine water on the durability of filling paste. Int. J. Green Energy 2018, 15, 864-873. [CrossRef]

4. Sun, Y.; Li, G.; Zhang, J.; Qian, D. Experimental and numerical investigation on a novel support system for controlling roadway deformation in underground coal mines. Energy Sci. Eng. 2020, 8, 490-500. [CrossRef]

5. Wang, C.X.; Liu, Y.; Hu, H.; Li, Y.Y.; Lu, Y. Study on Filling Material Ratio and Filling Effect: Taking Coarse Fly Ash and Coal Gangue as the Main Filling Component. Adv. Civ. Eng. 2019, 2019, 2898019. [CrossRef]

6. Cui, B.Q.; Liu, Y.; Guo, H.; Liu, Z.X.; Lu, Y. Experimental Study on the Durability of Fly Ash-Based Filling Paste in Environments with Different Concentrations of Sulfates. Adv. Mater. Sci. Eng. 2018, 2018, 4315345. [CrossRef]

7. Hu, Y.J.; Li, L.; Tian, J.Y.; Zhang, C.X.; Wang, J.; Yu, E.W.; Xing, Z.P.; Guo, B.W.; Wei, H.Y.; Huo, Z.Y.; et al. Effects of dynamic low temperature during the grain filling stage on starch morphological structure, physicochemical properties, and eating quality of soft japonica rice. Cereal Chem. 2020, 97, 540-550. [CrossRef]

8. Bede, A.; Scurtu, A.; Ardelean, I. NMR relaxation of molecules confined inside the cement paste pores under partially saturated conditions. Cem. Concr. Res. 2016, 89, 56-62. [CrossRef]

9. Sun, Y.; Li, G.; Zhang, J.; Qian, D. Stability control for the rheological roadway by a novel high-efficiency jet grouting technique in deep underground coal mines. Sustainability 2019, 11, 6494. [CrossRef]

10. Larson, K.J.; Basagaoglu, H.; Marino, M.A. Prediction of optimal safe ground water yield and land subsidence in the Los Banos-Kettleman City area, California, using a calibrated numerical simulation model. J. Hydrol. 2001, 242, 79-102. [CrossRef]

11. Dolezalova, H.; Kajzar, V.; Soucek, K.; Stas, L. Analysis of Surface Movements from Undermining in Time. Acta Geodyn. Geomater. 2012, 9, 389-400.

12. Manekar, G.G.; Shome, D.; Chaudhari, M.P. Prediction of Subsidence Parameters \& 3-D Analysis at Balaghat Underground Manganese Mine of MOIL Limited, India. In Proceedings of the ISRM European Rock Mechanics Symposium (EUROCK), Ostrava, Czech Republic, 20-22 June 2017; pp. 1075-1086.

13. Makeeva, T.G.; Trofimov, V.A. Earth surface subsidence caused by arbitrary underground mining. In Proceedings of the 21st International Scientific Conference on Advanced in Civil Engineering Construction-The Formation of Living Environment (FORM), Moscow State University of Civil Engineering, Moscow, Russia, 25-27 April 2018.

14. Abdikan, S.; Arikan, M.; Sanli, F.B.; Cakir, Z. Monitoring of coal mining subsidence in peri-urban area of Zonguldak city (NW Turkey) with persistent scatterer interferometry using ALOS-PALSAR. Environ. Earth Sci. 2014, 71, 4081-4089. [CrossRef]

15. Choudhury, P.; Gahalaut, K.; Dumka, R.; Gahalaut, V.K.; Singh, A.K.; Kumar, S. GPS measurement of land subsidence in Gandhinagar, Gujarat (Western India), due to groundwater depletion. Environ. Earth Sci. 2018, 77, 5. [CrossRef]

16. Zakharov, A.I.; Epov, M.I.; Mironov, V.L.; Chymitdorzhiev, T.N.; Seleznev, V.S.; Emanov, A.F.; Bykov, M.E.; Cherepenin, V.A. Earth Surface Subsidence in the Kuznetsk Coal Basin Caused by Manmade and Natural Seismic Activity According to ALOS PALSAR Interferometry. IEEE J. Sel. Top. Appl. Earth Observ. Remote Sens. 2013, 6, 1578-1583. [CrossRef]

17. Marschalko, M.; Yilmaz, I.; Kubecka, K.; Bouchal, T.; Bednarik, M.; Drusa, M.; Bendova, M. Utilization of ground subsidence caused by underground mining to produce a map of possible land-use areas for urban planning purposes. Arab. J. Geosci. 2015, 8 , 579-588. [CrossRef]

18. Zhao, X.; Fourie, A.; Veenstra, R.; Qi, C.C. Safety of barricades in cemented paste-backfilled stopes. Int. J. Miner. Metall. Mater. 2020, 27, 1054-1064. [CrossRef]

19. Yan, B.Q.; Ren, F.H.; Cai, M.F.; Qiao, C. Influence of new hydrophobic agent on the mechanical properties of modified cemented paste backfill. J. Mater. Res. Technol.-JMRT 2019, 8, 5716-5727. [CrossRef]

20. Zhao, M.; Zhang, X.; Zhang, Y.J. Effect of free water on the flowability of cement paste with chemical or mineral admixtures. Constr. Build. Mater. 2016, 111, 571-579. [CrossRef]

21. Yu, Z.B.; Zhu, S.Y.; Wu, Y.; Yu, H.T. Study on the structural characteristics of the overburden under thick loose layer and thin-bed rock for safety of mining coal seam. Environ. Earth Sci. 2020, 79, 9. [CrossRef]

22. Sun, Y.T.; Bi, R.Y.; Chang, Q.L.; Taherdangkoo, R.; Zhang, J.F.; Sun, J.B.; Huang, J.D.; Li, G.C. Stability Analysis of Roadway Groups under Multi-Mining Disturbances. Appl. Sci. 2021, 11, 7953. [CrossRef]

23. Zhou, Y.J.; An, B.F.; Zhang, Z.J.; Xue, S.; Hao, X.F. Study on Developmental Rule of Earth's Surface Fissures under Thick Unconsolidated Layer's Condition of Thin Bedrock in Coal Mining. Disaster Adv. 2013, 6, 279-288.

24. Yu, Z.B.; Zhu, S.Y.; Guan, Y.Z.; Hu, D.X. Feasibility of Modifying Coal Pillars to Prevent Sand Flow Under a Thick Loose Layer of Sediment and Thin Bedrock. Mine Water Environ. 2019, 38, 817-826. [CrossRef]

25. Zhou, D.W.; Wu, K.; Cheng, G.L.; Li, L. Mechanism of mining subsidence in coal mining area with thick alluvium soil in China. Arab. J. Geosci. 2015, 8, 1855-1867. [CrossRef] 
26. Sun, Y.; Li, G.; Zhang, J.; Sun, J.; Huang, J.; Taherdangkoo, R. New Insights of Grouting in Coal Mass: From Small-Scale Experiments to Microstructures. Sustainability 2021, 13, 9315. [CrossRef]

27. Yang, W.F.; Xia, X.H. Prediction of mining subsidence under thin bedrocks and thick unconsolidated layers based on field measurement and artificial neural networks. Comput. Geosci. 2013, 52, 199-203. [CrossRef]

28. Gu, S.C.; Yao, B.Y. Study on Strata Behavior Regularity of 1301 Face in Thick Bedrock of Wei-qiang Coal Mine. In Proceedings of the 2nd International Seminar on Advances in Materials Science and Engineering (ISAMSE), Singapore, 28-30 July 2017.

29. Hou, D.F.; Li, D.H.; Xu, G.S.; Zhang, Y.B. Superposition model for analyzing the dynamic ground subsidence in mining area of thick loose layer. Int. J. Min. Sci. Technol. 2018, 28, 663-668. [CrossRef]

30. Morris, P.A. Fine fraction regolith chemistry from the East Wongatha area, Western Australia: Tracing bedrock and mineralization through thick cover. Geochem.-Explor. Environ. Anal. 2013, 13, 21-40. [CrossRef]

31. Sun, Y.T.; Li, G.C.; Zhang, J.F. Developing Hybrid Machine Learning Models for Estimating the Unconfined Compressive Strength of Jet Grouting Composite: A Comparative Study. Appl. Sci. 2020, 10, 1612. [CrossRef]

32. Xu, Y.C.; Luo, Y.Q.; Li, J.H.; Li, K.Q.; Cao, X.C. Water and Sand Inrush During Mining Under Thick Unconsolidated Layers and Thin Bedrock in the Zhaogu No. 1 Coal Mine, China. Mine Water Environ. 2018, 37, 336-345. [CrossRef]

33. Harper, J.T.; Humphrey, N.F.; Meierbachtol, T.W.; Graly, J.A.; Fischer, U.H. Borehole measurements indicate hard bed conditions, Kangerlussuaq sector, western Greenland Ice Sheet. J. Geophys. Res.-Earth Surf. 2017, 122, 1605-1618. [CrossRef]

34. Seo, W.S.; Kim, J.B. Filling analyses of solder paste in the stencil printing process and its application to process design. Solder. Surf. Mt. Technol. 2013, 25, 145-154. [CrossRef]

35. Sun, Y.T.; Li, G.C.; Zhang, J.F.; Huang, J.D. Rockburst intensity evaluation by a novel systematic and evolved approach: Machine learning booster and application. Bull. Eng. Geol. Environ. 2021, 80, 8385-8395. [CrossRef]

36. Chen, S.J.; Li, Y.Y.; Guo, W.J.; Lu, C.; Wang, H.Y.; Yin, D.W. Similar materials of colliery filling for physical simulation experiment. Mater. Res. Innov. 2015, 19, 304-307. [CrossRef]

37. Li, K.; Stroeven, P.; Stroeven, M.; Sluys, L.J. Estimating permeability of cement paste using pore characteristics obtained from DEM-based modelling. Constr. Build. Mater. 2016, 126, 740-746. [CrossRef]

38. Sun, Y.T.; Zhang, J.F.; Li, G.C.; Wang, Y.H.; Sun, J.B.; Jiang, C. Optimized neural network using beetle antennae search for predicting the unconfined compressive strength of jet grouting coalcretes. Int. J. Numer. Anal. Methods Geomech. 2019, 43, 801-813. [CrossRef] 